\title{
EDITORIAL
}

\section{PROHIBITION LEGISLATION TO BE ENFORCEABLE MUST BE REASONABLE.}

\section{$\mathbf{T}$}

HE prohibition amendment would very likely have been adopted if submitted to a vote of the people; however, some legislators are endeavoring to go beyond what was popularly supposed to be contemplated by it. The constitutional amendment won popular sanction because of the general idea and representation that it was designed to destroy the liquor traffic, but State and Federal legislators have attempted, and successfully, to extend the prohibition so that many industries and businesses will be adversely affected, injured or disturbed, which portends that the people will, in turn, be inconvenienced and compelled to pay higher prices for articles containing alcohol, even if lawfully obtainable; further, that American commerce will be placed at a disadvantage in foreign competition, unless liberal and adequate provisions are made for the use of tax-free, industrial alcohol.

Congressman Pou, of North Carolina, a veteran and stalwart prohibitionist, declared in the House that the enforcement bill then under discussion never could be put into effective operation. Seemingly, if not in fact, the action of the House was in response to the demand of many influential and active constituents of the members, and it has been said that one of the functions of the House is to appease the constituency, relying on the Senate to shape the legislation, making it more conformable to reason and the Constitution. There is another assumption which has been occasionally, if not frequently, expressed in political circles, that there is no intention of eliminating the prohibition question, because it makes fine campaign material. Whether such assertion is the creation of faulty imagination or well-founded suspicion, the course in Congress and in some State Legislatures gives some color of plausibility to that charge. Unquestionably some campaigners have successfully and successively fought their way into legislative halls with such armament and ammunition of words and, perhaps, of action. There are limits of practicality to which prohibition laws can not be made to apply, and then they not only are non-enforceable but jeopardize the accomplishment of that which it is practical to attempt doing.

The prohibition enforcement bill is considerably more rational than it would have been if the intent of some of the prohibition leaders had been incorporated in the law by the legislators. The statement was reported of a demand "that search and seizure be authorized without a warrant, or that warrants be issued without requiring testimony in support of requests for them; that such inclusion was necessary for the enforcement of the amendment." To carry such extreme 
provisions into effect would probably have necessitated further that trial by jury be done away with, for it is somewhat questionable whether the people of the United States are ready for such procedure. Under some of the prohibition legislation enacted and under consideration there is danger of a system of espionage being developed and encouraged which is apt to excite hostility, and "arouse a spirit of revulsion in the minds of that large class of citizens who are prohibitionists under the restraint of their sense of practicality."

In the excess of their zeal many prohibition advocates and some legislators proceed on the assumption that any liquid which they are pleased to pronounce intoxicating can be put under the ban. Hence we have the proposals in Federal and State legislation to forbid the manufacture of medicines, cosmetics, flavoring extracts, etc. A multiplicity of exacting details create possibilities of unintentional violations for which the severest penalties are imposed. The amendment may confer unlimited authority for any and all provisions that have been incorporated in state and national laws, but we question the moral right of the extreme use made of it in some of the enactments.

It is the duty of a physician to prescribe and administer medicines according to his judgment of the case under treatment, and of the pharmacist to prepare and dispense medicines, even though they contain alcohol. Unnecessary hardships should not be imposed upon them in this service. The public employs preparations containing alcohol for hygienic, culinary and other purposes, in the purchase of which the individuals should not be subjected to unreasonable investigation of their intent. There are needs for alcohol in the arts and industries, and hindrances in the use and application will interfere with trade to an extent that may make competition in foreign trade impossible or very difficult, whereas every possible encouragement should be given to extend the use of industrial alcohol.

It is to be hoped that the Senate will shape the enforcement legislation to conform with reason and the Constitution, giving proper and just consideration to the people. There should be uniformity in State laws applying to such legislation and the prohibition question should be removed as a subject of political and party contention.

There is no country in the world in which everything can be provided for by the laws, or in which political institutions can prove a substitute for common sense and public morality.-De Tocqueville.

E. G. E. 